\title{
History Page: Leaders in MSK Radiology Karl Dussik, 1908-1968: Pioneer of MSK Ultrasonography
}

\author{
Iwona Sudoł-Szopińska, Prof., MD, PhD ${ }^{1}$ () \\ ${ }^{1}$ Department of Radiology, National Institute of Geriatrics, \\ Rheumatology and Rehabilitation, Warsaw, Poland \\ 2 Department of Health Sciences (DISSAL), Università di Genova, \\ Genova, Italy \\ ${ }^{3}$ IRCCS Ospedale Policlinico San Martino, Genova, Italy \\ ${ }^{4}$ Freelancer, author of popular historical science books and articles, \\ Warsaw, Poland
}

Carlo Martinoli, Prof., MD ${ }^{2,3}$ Marta Panas-Goworska ${ }^{4}$

\author{
Address for correspondence Iwona Sudoł-Szopińska, Prof., MD, PhD, \\ Department of Radiology, National Institute of Geriatrics, \\ Rheumatology and Rehabilitation, St. Spartańska 1, Warsaw, 02-637, \\ Poland (e-mail: sudolszopinska@gmail.com).
}

Semin Musculoskelet Radiol 2021;25:184-185.
Abstract
Keywords
- Karl Dussik
- ultrasonography
- history
This history page in the series "Leaders in MSK Radiology" is dedicated to the memory and achievements of Karl Theodore Dussik, the Austrian neurologist and psychiatrist from the University of Vienna who is recognized as the pioneer of ultrasonography.

Ultrasound was discovered at the end of the 18th century by two scientists: Charles Jurine, a swiss zoologist (1751-1819), and Lazzaro Spallanzani (1729-1799), an Italian psychologist. They studied bats and found that they were not able to navigate their environments with plugged ears or covered mouths. Unfortunately, these researchers were unable to draw accurate conclusions from their experiments at the time. More than a hundred years later, innovative echolocation tools (i.e., sonars) were the next step in ultrasonography development. They were initially used mainly for military purposes, especially during World War I. ${ }^{1}$ In 1917, Paul Langevin, Pierre Curie's student, and Constantin Chilowsky constructed a submarine sound generator made of quartz crystals and two steel plates; their device is thought to be the prototype of modern ultrasound devices. However, it took another several decades for ultrasound to be used in diagnostic medicine for echolocation.

In 1937, Karl Dussik, a neurologist and psychologist from the University of Vienna, tried to use a device called a reflectoscope to examine the human brain ( $\mathbf{- F i g . 1}$ ), but his research was interrupted by the outbreak of World War II. ${ }^{2}$ After graduation in 1931, Dussik was working under Professors Erwin Stransky and Otto Pötzl. In the article dated 1936 describing his pioneer work in applied psychopathology,
Stransky mentioned Dussik, who was assisting him at the time, as a "very studious and talented" young physician.

When Dussik returned from the front to the Institute of Physics of the University of Vienna, he and his brother Friedrich, a physicist, prepared a special workplace, a type of bathtub with transducers connected to it. The image obtained by this device was fixed on photographic paper, but the ensuing results carried a high risk of error.

Quite unfairly, too little attention has been given to Dussik's research from the 1950s on. When he moved to Boston, he and his colleagues began studies on ultrasound examinations of articular tissues. ${ }^{3}$ They were the first to examine in vivo the anatomical components of the joints of the human body, and for each of them, they provided average values and standard deviations of attenuation constants. They established attenuation values for these tissues (e.g., very low for liquids, low for adipose tissue, medium for striated muscles, high for tendons, and very high for bones) and suggested explanations for their different echogenicity. In addition, they were the first to describe two phenomena: fiber anisotropy and layer anisotropy. These researchers also hypothesized which pathologic factors may influence attenuation values, such as increased water or fat content, cellular organization, or connective tissue content.
Issue Theme Imaging of Pediatric MSK Diseases; Guest Editors, Alberto Bazzocchi, MD and Giuseppe Guglielmi, MD (c) 2021. Thieme. All rights reserved. Thieme Medical Publishers, Inc., 333 Seventh Avenue, 18th Floor, New York, NY 10001, USA
DOI https://doi.org/ 10.1055/s-0040-1722207. ISSN $1089-7860$. 


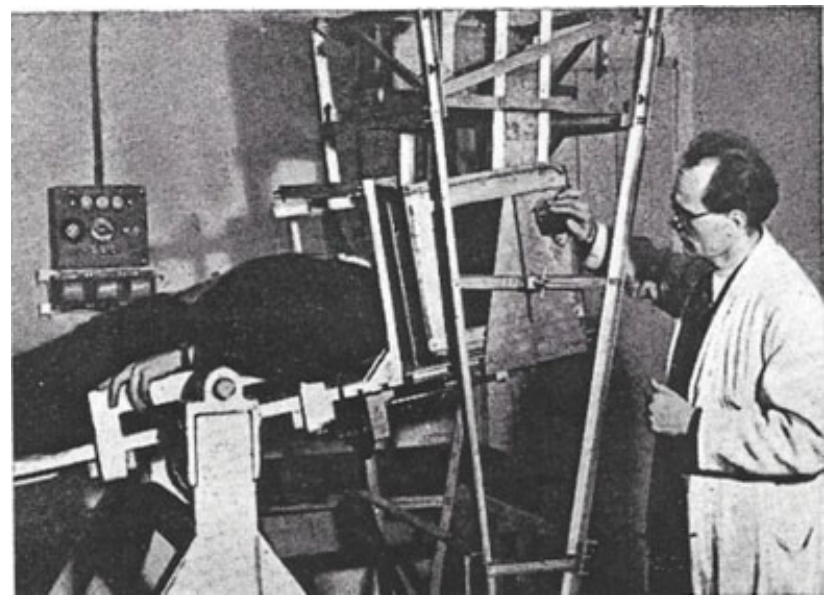

Fig. 1 Karl Dussik operating his reflectoscope for human brain examination (https://www.genesis-ultrasound.com/venous-ultrasound.html).

Karl Dussik, despite his lack of success in making useful and valid images of the brain from his transmission techniques, must be credited for being the first medical profes- sional to apply ultrasound as a diagnostic tool, and in particular, in a planned and organized fashion. Douglas Gordon, a British ultrasound pioneer, in his 1964 book Ultrasound as a Diagnostic and Surgical Tool, expressly called Dussik the "father of ultrasonic diagnosis." The studies conducted by Dussik inspired future generations of young researchers who developed and refined this imaging modality, making it one of the most used tools in musculoskeletal imaging today.

\section{Conflict of Interest}

None declared.

\section{References}

1 Kane D, Grassi W, Sturrock R, Balint PV. A brief history of musculoskeletal ultrasound: 'From bats and ships to babies and hips.'. Rheumatology (Oxford) 2004;43(07):931-933

2 Frentzel-Beyme B. Ultraschallmuseum - Historische Notizen. Ultraschall Med 2012;33(03):298-299

3 Dussik KT, Fritch DJ, Kyriazidou M, Sear RS. Measurements of articular tissues with ultrasound. Am J Phys Med 1958;37(03): $160-165$ 